\title{
SYSMÄ COMMUNITY CURRENCY: AN ANALYSIS OF ITS SUCCESS FROM THE PERSPECTIVES OF PURPOSES, STAKEHOLDERS AND PROMOTION
}

\author{
Marcus Petz ${ }^{1}$, Teppo Eskelinen²
}

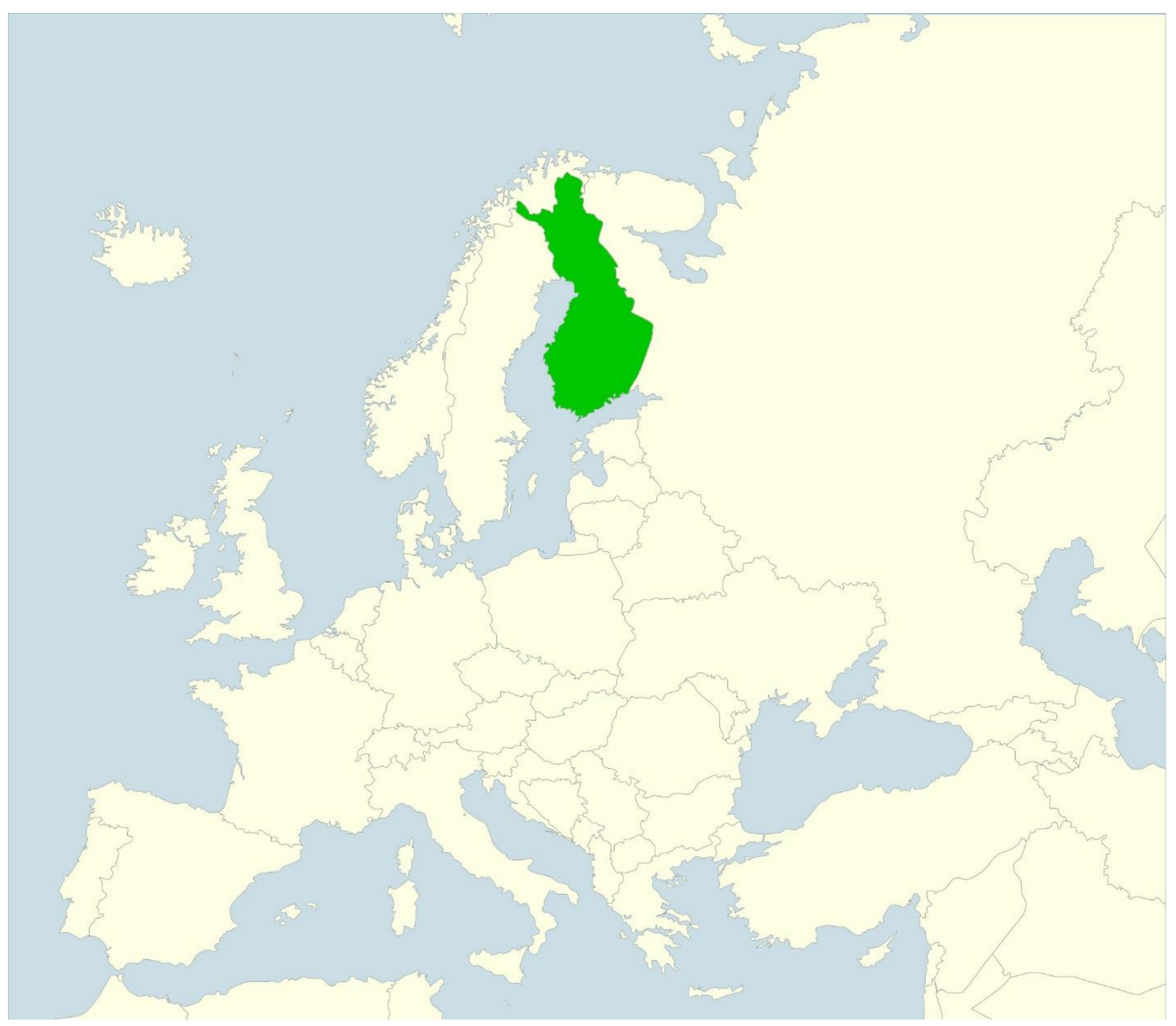

\footnotetext{
${ }^{1}$ Marcus Petz BSc., MSc. Doctoral Student, Department of Philosophy and Social Sciences, University of Jyväskylä, Finland, ORCID: 0000-0002-1478-8121; e-mail: Marcus.kit.petz@student.jyu.fi

2 Teppo Eskelinen Dr.Soc.Sc. Senior Lecturer Department of Philosophy and Social Sciences, University of Jyväskylä, Finland; e-mail: teppo.h.i.eskelinen@jyu.fi
} 
Abstract: The article is a case study of a local currency, recently introduced in the rurally situated municipality of Sysmä, Finland. As a small community suffering a gradual population decline since the 1960s, Sysmä municipality has begun to innovate with several projects this millennium. Here, we analyse as a narrative and from the viewpoint of experienced tensions, the introductory phase of one of these projects, which strictly is a hyper-local currency acting as a system of account. It is noted that there are unclarities regarding the purpose of the scheme, and that different stakeholders and other observers do have varying ideas about this purpose. Political decisions over limiting rights of issuance of the local currency to locally registered businesses; and its exclusive use for local association subsidies have created some challenges to the acceptance of the currency. Further, the currency has limited uptake due to technical issues, injudicious use of the marketing mix and difficulties with innovating in a rural area. Noting these issues and the peculiarity of the scheme amidst other typical European local currency schemes, the article also points out benefits of the scheme and potential future developments.

Keywords: Rural resilience, area effects, demographic challenge, green economics

Abstrakti: Artikkeli on tapaustutkimus paikallisrahajärjestelmästä, jota kokeiltiin äskettäin maalaisympäristössä Sysmän kunnassa. Paikallisraha on yksi innovaatiivisista aloitteista, joita kunta on tehnyt tällä vuosituhannella torjuakseen jo 1960-luvulta alkaen käynnissä ollutta väestökatoa. Tässä artikkelissa tutkitaan paikallisrahan käynnistysvaihetta siihen sisältyneiden ristiriitojen näkökulmasta. Artikkelissa todetaan, että järjestelmä kärsi epäselvästä tavoitteenasettelusta, ja että eri osallisilla oli tavoittesta vaihtelevia ja ristiriitaisia käsityksiä. Paikallisrahan sosiaalista hyväksyntää heikensivät päätös rajoittaa rahaa vastaanottavien yritysten joukko kunnassa kirjoilla oleviin yrityksiin, sekä paikallisten yhdistysten tukien maksaminen vain paikallisrahassa. Lisäksi paikallisrahan käytön omaksumista rajoittivat tekniset haasteet, harkitsematon tiedotusstrategia sekä maaseutualueella innovoinnin yleiset haasteet. Artikkelissa eritellään myös Sysmän paikallisrahan erityispiirteitä kansainvälisessä vertailussa sekä järjestelmän onnistumisia ja tulevaisuuden kehitysmahdollisuuksia.

Avainsanat: Maaseudun resilienssin, alueelliset vaikutukset, väestön ikääntymishaaste, ekologinen talous

Sammanfattning: Artikeln utgör en fallstudie av en lokalvaluta som introducerades nyligen i den finska landbygdskommunen Sysmä. En liten kommun vars befolkning minskat gradvis ändå sen 1960-talet, Sysmä har börjat testa innovationer i ett antal projekt sedan millenieskiftet. I artikeln analyserar vi inledningsfasen av ett av dessa projekt, som gäller ett försök med en egen lokalvaluta inom ett mycket begränsat geografiskt område. Analysen är i narrativ form och tar utgångspunkt i upplevda spänningar. Vissa otydligheter konstateras vad gäller syftet med projektet, där olika intressentgrupper och andra observatörer verkar ha olika uppfattningar. Politiska diskussioner har t ex gällt att begränsa valutaskapande aktiviteter till företag registrerade i kommunen resp att använda valutan uteslutande som stöd för det lokala civila samhället; sådana offentliga diskussioner har ställt hinder i vägen för en bred acceptans. Valutan har dessutom anammats endast i begränsad omfattning som följd av en rad olika faktorer, som tekniska svårigheter, ogenomtänkta torgföringsstrategier samt allmänna svårigheter vad gäller innovationer på landet. Initiativet skiljer sig även från andra europeiska projekt för skapandet av lokalvalutor. Dock pekar artikeln på ett antal fördelar med systemet samt på tänkbara framtida utvecklingsmöjligheter.

Nyckelord: Landsbygdsresiliens, markanvändning, demografisk utmaning, grön ekonomi 
Zusammenfassung: Der Artikel ist eine Fallstudie einer Lokalwährung, die kürzlich in der ländlich gelegenen Gemeinde Sysmä in Finnland eingeführt wurde. Als kleine Gemeinde, die seit den 1960er Jahren unter einem allmählichen Bevölkerungsrückgang leidet, hat die Gemeinde Sysmä seit der Jahrtausendwende mehrere innovative Projekte begonnen. Hier erzählen wir unter dem Gesichtspunkt erlebter Spannungen die Einführungsphase eines dieser Projekte, bei dem es sich streng genommen um eine hyperlokale Währung handelt, die als Abrechnungssystem fungiert. Es wird angemerkt, dass es Unklarheiten hinsichtlich des Zwecks der Währungsordnung gibt und dass verschiedene Stakeholders und andere Beobachter unterschiedliche Vorstellungen von diesem Zweck haben. Politische Entscheidungen über die Beschränkung der Ausgabe der lokalen Währung an lokal registrierte Unternehmen und sowie ihre ausschließliche Verwendung für lokale Vereinszuschüsse haben die Akzeptanz der Währung vor einige Herausforderungen gestellt. Darüber hinaus hat sich die Währung aufgrund technischer Probleme, unsachgemäßer Verwendung des Marketing-Mix und Schwierigkeiten bei der Innovation in einem ländlichen Gebiet nur begrenzt durchgesetzt. In Anbetracht dieser Probleme und der Außergewöhnlichkeit inmitten anderer typischer europäischer Lokalwährungsordnungen werden in dem Artikel auch die Vorteile des Systems und mögliche künftige Entwicklungen hervorgehoben.

Schlüsselwörter: Resilienz des ländlichen Raums, Flächeneffekte, demografische Herausforderung, Ökologische Ökonomik

\section{Introduction}

As various remedies to the current problems of spatial concentration of wealth are sought, some rural locations are turning to innovative solutions. Such innovations aim at creating new kinds of mechanisms; both to foster economic activity in the geographical periphery, and to strengthen local identities and attachment to the area. Amongst such innovations, community currencies (CCs) might be emerging as an interesting category. As new kinds of economic tools, they create a structural incentive to consume locally, while also, when well-functioning, increase the velocity of money in the local economy (de La Rosa and Stodder, 2015; Gelleri, 2009). There is a caveat to this, the CC on its own does not do this, it depends on how the particular scheme is run. Therefore, factors such as demurrage, microloans or the presence of cash can all stimulate spending (de La Rosa and Stodder, 2015). In addition to these positive economic outcomes, they aim at re-enforcing local identities. Mostly, such systems have existed in urban areas, yet there are good reasons why community currencies can be a component in rural economic regeneration.

In this article, we analyse a recent experience with a community currency in a rural setting, which took place in Sysmä, Finland. The case is noteworthy in many respects, one of which is its status as the first community currency of its kind in Finland. The success of the initiative was mixed, and here we elucidate its relative merits and shortcomings. It is important to record the introduction of a community currency and to report what is found in early phases rather than only to report those projects which have been successful. We thus, undertook an empirical investigation, as this was now interesting, rather than one based more on hypothesis testing (de Groot, 2014).

Our analysis locates the scheme amongst community currencies, shows tensions related to the scheme, and the various perspectives of different stakeholders. We first give the general context, then explicate the data and methods, and then move to the analysis.

\section{Background to Community Currencies and Rural Studies}

Typically, politics and innovation within the economy have traditionally been approached as questions regarding production and exchange.

In this context, money is seen as merely a technical issue or a more convenient alternative to barter (Samuelson, 1997). Yet today, we see an increasing awareness of the role of monetary 
institutions in shaping material, social and even cultural relations, making way to a host of monetary innovations, including community currencies. The purpose of community currencies is to reclaim control over (parts of) the economy by a currency accepted only within a given community, and to create economic stimulus at the local level. The communities in which a community currency is embedded, can either be: geographical communities; of people delimited in space and time, or communities of interest; the members of which share features in common (Obst and others, 2002).

Complementary currencies are then economic stimuli implementing the policy mix (Eliadis and others, 2005), but at the local (or on a targeted population if it is a community of interest) rather than national or even regional level. As such, they do not conform to the usually found regional development nor structural national economic policies as to the paradigm they are operating under, but rather a "new paradigm" (Dower, 2013).

Nevertheless, despite emerging innovations around money, government institutions still largely dominate the discourse around money and economics. This is reflected in community currencies often being called complementary currencies (Fare and Ahmed, 2017). They are considered complementary to a national or official or fiat currency, backed up by state institutions, practically seen as synonymous to "money", despite the short history of national currencies (Cohen, 1998).

As there is a large variety of community currencies of different kinds (Nishibe, 2018; Lietaer, 2001), estimated at over 4000 recent examples (Lietaer and Dunne, 2013), they can be typologised, at least to some extent (Martignoni, 2012). While some scholars note that generally, "attempts to build typologies and to name things properly have always been disappointing" (Blanc, 2011 , 4), typologies can be helpful in locating individual community currency schemes within the field. Possible conceptual tools for doing this classification we propose would be generational, geographical, and purposeful.

Rather than trying to classify currencies to this or that category, what is more useful is to describe the facets of a currency and the community of users. That is to look at the usufruct of the currency which considers the property rights inherent in money (Fox, 2008).

Research on community currencies is part of a wider endeavour to look at how resilience can be strengthened in rural communities (Christopherson and others, 2010; Cumming and others 2005; Fieldsend 2013). The assessment of the relevance of community currencies to rural areas in Finland depends on how the existing monetary institutions (particularly the euro) are seen from the viewpoint of allowing different policies ${ }^{3}$. In any case, the functioning of the contemporary market economy with related spatial concentration tendencies often results in rural areas becoming perceived (Stingl, 2015), and then made peripheral to the market centres (Weber, 1978), which are commonly in urban areas (van Meeteren and Poorthuis, 2018). Thus, such rural areas have a relatively low relational capital and lower access to financial capital (Hornborg, 2009). Community currencies which are geographically based in rural communities then seek to stimulate local wealth and strengthen local supply chains by increasing the velocity of money in the local economy. The pressing need for rural finance, and its lack, is a driver for such alternatives. The rural context of this community currency was a motivating factor in researching it.

Rural currencies have been successful in the past, notably as Local Exchange Transfer Schemes (LETS) schemes (Aldridge and others, 2003). These schemes evolved from employment inclusion programmes and typically combine services and products such as rooms for rent, food or other locally produced goods (Kennedy and others, 2012). Other rural currencies have made use of time-banking (Eskelinen, 2018) or mutual credit clearing (Greco, 2012). The Lewes Pound (UK) (The Lewes Pound, 2018) and the Waldviertler (Austria) (Waldviertler - Verein für regionales Wirtschaften 2016) are examples of recent viable rural local currencies.

\footnotetext{
${ }^{3}$ The euro system as implemented has had major impacts on European regional and country levels (Varoufakis 2016), yet there are effects too between core and peripheral areas within countries (Dower 2013).
} 


\section{Context to Finland and Sysmä}

Finland follows the general demographic trends (Heikkilä, 2003), as it continues to suffer a mass rural to urban migration (Champion and Hugo, 2003) and sees wealth steadily draining from rural areas to Helsinki (Grunfelder, 2018; Saarinen, 2011). To counter this trend, many rural development initiatives have been introduced ${ }^{4}$, along with government spatial policy. A good case study of this synergy can be made of the 2013 "Local Food - But of Course!" (Maa- ja metsätalousministeriö, 2013) government programme that has been introduced in awareness of the institutional environment created by the European Union and government administration as set out in the 2009 Act on Regional Development (MLIT, 2017) and updated in 2014 (Manelius, 2016). These initiatives range from ones mostly designed to generate visibility for a rural municipality to serious economic regeneration initiatives. The introduction, of the country's first rural local currency, in Sysmä takes place in this context.

Sysmä is found within the Päijät-Häme Region of Finland. The main population cluster in the Sysmä municipality is called Sysmä and is considered a village by the residents, though the municipality contains some sparsely populated rural areas and is smaller than the historic Sysmä area or even the area of Sysmä economic influence. Much of the region has suffered gradual rural population decline since the 1960s (Hahl and others, 2014). Sysmä municipality's population was 9282 in 1960 (MMM, 1964), and 3820 as of July 2018 (OSF, 2018). As Sysmä municipality depends on local taxes, population decline has provided some difficulties with funding services to the level they historically have enjoyed.

More recently, the area effects in the Päijät-Häme Region, which Sysmä is a part of, have manifested reduced house prices and a dearth of young adults, who are needed to make the community function effectively. There is a forestry and farming community, although the nature of its income generating characteristics has shifted in emphasis with a greater amount derived from tourism, service provision (such as camping, boating, and events like the Suvisoitto music festival), and not from production of agricultural products (which includes timber or unprocessed food crops (European Union, 2004)). It can thus be described as post-productivist agriculture and replicates a trend seen in other Northern European countries such as the UK (Almstedt, 2013; Libery and Kneafsey, 1998).

Yet, the local culture has a resilience to external shocks which includes an impetus for innovations. Sysmä has seen drastic changes in the past and had to, and did change the customary agricultural production on account of the world commodity prices and demand (Vanhanen, 2015) in the 19th century and the mid-20th century with respect to arable and dairy crops. In this millennium, Sysmä municipality has begun to innovate with several projects to counter demographic and economic decline. These include e-residency (Tuomikoski, 2018), membership of the International Organisation of Book Towns with the Sysmän Kirjakyläpäivät (Book-village Days) literary festival, (Seaton, 1999) and a trial of a community currency (Talasterä and Sources, 2017), which this case study is about. A partial recognition of this situation led initially to an arts and cultural revival called Yksi Sysmä (the one and only Sysmä) over the last decade. It has been described as a "declaration of independence". The spirit of innovation is emphasised by the Sysmä money project website, which proclaimed "Sysmä is historically known for its creative craziness". The official name of the Sysmä money project was Sysmän kuponkieuro ja pienyrittäjien verkosto (Sysmä euro-voucher and small entrepreneur network) (PHL, 2017). Local people tend to describe the area positively, particularly in comparison to nearby Hartola and Padasjoki.

\footnotetext{
4 www.maaseutu.fi/en/the-rural-network/rural-development-program/ and mmm.fi/en/project-and-legislation and ec.europa.eu/agriculture/sites/agriculture/files/rural-development-2014-2020/country-files/fi/factsheetmainland_en.pdf details many of those projects and their aims.
} 
A significant exogenous factor for Sysmä is the population that is not permanently resident within the municipality. A useful aim is thus to identify and describe this "Sysmä diaspora", and the alternative home-owner sub-population within it, which may have a more significant economic relationship with Sysmä. The economic inputs from the diaspora need to be clarified, both in amount, frequency and amplitude. Into this social system, the introduction of a community currency may lead to economic and perceptual effects from the Sysmä currency on the diaspora, and particularly on the alternative home-owner sub-culture.

Attempts have been made to work with other local municipalities on a regional scale. They have not been very successful in working with Hartola, the nearest municipality, with the feeling that Hartola has "lost hope". However, several of the nearby municipalities have formed a partnership to maximise tourist promotion and this is happening under different names. "Gateway to Finnish Lake District" [sic] (Lahti Region Ltd., 2017) is one tagline used as part of an alternative branding aimed at tourists for this "Lahti Region". There is a love-hate relationship with the nearest city of Lahti, which as the largest urban area in the region both attracts customers from outside the city; and simultaneously leads to impoverishment of the regional economy, thus deprived of custom.

The definitions of who is partnered with are in a state of flux. This shifting sands institutional environment (e.g., the recently attempted country-wide social and health service reform SOTE ${ }^{6}$ (Vauramo, 2018)) makes planning initiatives difficult, and means competition rather than cooperation may result between municipalities and even within municipalities. Similarly, areas of responsibility may be neglected as they do not fall within one person's, division's or even municipality's remit.

\section{Research aims, data and methods}

This article is a case study of the trial phase of the sysmä local currency (called "sysmä", with a lower case "s"). The article has two general aims. First, to analyse the prospects of sysmä in terms of its potential as a radical parallel currency (Brunnhuber, 2015) partially done by evaluating its implementation. Second, to analyse the relation of different stakeholders to the community currency initiative in the sense of experienced ownership of the scheme and expressed attitudes towards it.

Radical parallel currency means not only to accelerate the circulation velocity of money locally, but also to facilitate counter-urbanisation (Cloke, 1985). What potential does such a complementary currency have in mitigating the area effects which a rural area suffers from? This would mean finding a stimulus to transition and localisation, and identifying another dynamic that is a viable alternative to rural decline and village death (Cartwright, 2013; Kotilainen and others, 2015; Pattison, 2004).

When conducting the research, the identification of stakeholder groups was instrumental in analysing, how different groups in Sysmä related to the community currency initiative. Stakeholder analysis is typically carried out in organisation theory, sometimes defining stakeholders as "any group or individual who can affect or is affected by the achievement of the organization's objectives" (Friedman and Miles, 2006, 1), or even as "those groups without whose support the organization would cease to exist" (Freeman, 2010,31). The object of analysis can then be extended from organisations to transformative initiatives, as is often done when

\footnotetext{
${ }^{5}$ In diaspora studies, diaspora is a term that has widened in meaning, in application, yet those connected with Sysmä exhibit aspects which conform to the definitions of an internal or settlement diaspora. Namely: 1. Dispersion - from the Sysmä area; 2. Homeland orientation - with frequent interactions; and 3. Boundary-Maintenance, which can be assessed by "to what extent and in what forms boundaries are maintained by second, third and subsequent generations" (Brubaker 2005, 7). The last criterion is incipient, and time will reveal if there really is a meaningful Sysmä diaspora or just recent emigrants. Describing this diaspora is complicated by a lack of clarity as to what proportion have a historical connection with Sysmä, the wider region or even no recent connection, but are wealthy Helsinkians with alternative homes in the area. The latter may of course adopt a Sysmä identity, which raises another question around diaspora as a "category of practice" or a "constructed identity" which may not conform to the "classical diaspora paradigm", see (Toninato, 2009) for a discussion around this.

${ }^{6}$ SOTE stands for Maakunta ja sosiaali- ja tervyspalvalut uudistus, which is the county and social- and health service renewal. Within this is not just service renewal, but also a reorganisation of municipal boundaries and thus, possible political bias creeping in.
} 
analysing "stakeholder-motivated participation", typical for example, in nature conservation and global sustainability initiatives (Hemmatti, 2002). This starting point was used to analyse, how participation or "sense of ownership" (Hemmatti, 2002, 90) varies between different user groups of the scheme.

The material collected for the research comprises various data subsets. Firstly, the principal investigator acquired general knowledge of the project by contacting the key actors and visiting Sysmä prior to the introduction of the currency. He was able to interview the project manager and the head of the municipality. Another encounter with this project manager occurred during the Finnish Social Forum 2018. Further contact was attempted with the technical provider (Arantio Oy), and the main funder (Päijät-Hämeen Liitto) provided official documentation of the project.

Secondly, the currency introduction phase was observed with the investigator physically staying in Sysmä in July 2018, using deep hanging out (Geertz, 2000) as a co-performative witness. This differs from the similar participant observation by the expression of solidarity via the community development research (Hennink, 2013) actively sharing in the processes going on with those studied so that a "witnessing" (Madison, 2010, 24) from within a community's culture is possible (Hennink, 2013; Madison, 2010). It derives from an Artistic Research Method from performance art (Petz, 2017). A daily journal was kept while in Sysmä. Images were taken using a mobile phone of relevant literature and usage of the currency and local marketing aspects of the currency and the community. The municipal archives were also consulted. The aim here was thick description (Ponterotto, 2006) of all the cultural features, which might impact on the economic ecology of money usage, which could have a bearing on the Sysmä money. After the field trip, a project evaluation meeting was also attended by two of the research team where some preliminary findings and expert opinion were presented.

Thirdly, during the observation period, around twenty informal discussions and semi-structured interviews were done with Sysmä residents. These were done in English and Finnish, with a generally high level of English knowledge in the community, allowing effective communication. The collected voice-recorded data was transcribed using online transcription software. These rough transcripts were then later corrected due to mis-transcriptions. Identification of the key individuals or firebrands (Eckerberg and Forsberg, 1998) was performed, and several names and roles were identified for key individuals in the process of this project introduction. Snowball sampling (Goodman, 1961) was done, based on opportunity sampling from those that were listed online as participating businesses and those found to be members of participatory economy websites, who self-registered as living in Sysmä. Random sampling of those found at key locations in Sysmä i.e., the municipal office building, which in Sysmä's case also contains the library, the village market square, at a church free community meal, supermarkets and other local businesses, was carried out when in Sysmä. An ethnographic approach was taken due to the nature and situation of this complex social system. While many social systems are complex, in this case, the subject of study touched critical design challenges, which suggested an ethnographic procedure, would be apposite (Spotless, 2017; Fare and Ahmed, 2017). Lastly, some people in Sysmä have looked over it to see that their culture is appropriately contextualised.

Fourthly, various kinds of media data were collected. This includes collecting all articles from the local newspaper Sysmän Lähilehti which were written during the planning phase of the currency. These articles $(n=7)$ include reportings about planning meetings and on how the project proceeds, as well as one critical letter to the editor. In addition to the newspaper articles, data was collected by a webscrape of the Facebook Group Puskaradio Sysmä (bushtelegraph / grapevine Sysmä), where community issues are discussed, as well as the sysmä money project website.

Quantitative data could not be used. Low usage of the sysmä in the introduction phase (summer 2018) made gathering useful econometric data impossible, although electronic transaction data was made available to the research team if they should require it. Regrettably, no baseline survey was done of either the business or local consumer communities prior to the introduction of the currency.

The stakeholders were categorised into three groups: local consumers (those resident or working in Sysmä), local traders (those using the Sysmä in their businesses) and tourists (non-resident 
holiday makers). Yet, it was found that the alternative home-owners made this simplistic segmentation sub-optimal. Sysmä had been approached with a market research segmentation, based on the concept of a place as a brand (Zenker and Braun, 2010), thus perceiving the sysmä as a marketing innovation. As the unit of analysis was the Sysmä rural community, not only individuals as rational actors (Grüne-Yanoff, 2012) were considered, but also the identification of and import of potentially significant organisations or groupings as actants (Latour, 1996). They were taken into account to try and capture institutional factors (Ostrom, 2007), thus tackling weaknesses in mainstream influenced microeconomic theory (Falk, 2003; Gintis, 2000).

Analyses of data were performed using an interpretivist paradigm rather than a rational one. Data was continuously analysed and supplemented via journal entries, while collecting in the field and then while processing recordings. Recordings were transcribed using Otter Voice Notes (https://otter.ai/about). These outputs were then put in LibreOffice Writer (https://www.libreoffice.org/about-us/who-are-we/) and translated, where needed to English and corrected as there were transcription errors due to Otter using a corpus of predominantly business and military words and failing to pick up certain speakers' words - particularly those by women. While doing this, more ideas occurred and then the interviews, meeting recordings and journal entries were electronically coded (Basit, 2003) with an open coding type (Taylor and others, 2016, 181-188) using Atlas.ti (https://atlasti.com/product/what-is-atlas-ti/).

The analysis was based on content analysis of the various complementary data sets. This meant identifying frequently occurring themes in the data, and developing concepts on this basis (Taylor and others, 2016, 168-175). Then the initial typology was turned into an interpretation proper (Miller and Dingwall, 1997, 204-211). The purpose of the analysis was to synthesise data deriving from the various data sources, including observations, to enable assessment of the initiative. Further, stakeholder positions were identified. The cross-cutting purpose was to analyse the data from the social (acceptance), political (governance) and technical perspective. Care was taken to avoid contextual loss in the processing and analyses of data (Gubrium and others, 2012).

\section{Analysis: particularities of the scheme}

We now turn to describe the results of the analysis. The format is as follows. Firstly, we describe how the scheme can be analysed in relation to other comparable schemes internationally. Subsequently, we analyse potential tensions and perceptions of different stakeholders. The article finishes with a discussion on the future viability of the scheme, potential for improvement, and general assessment.

In terms of general classifications, the currency may be said to be local money, it is deliberately limited for businesses within Sysmä. Even more limiting, this was done by only allowing those with a business registered within the Sysmä municipality to have issuing rights for sysmä (PHL, $2019,10)$. Furthermore, it is hyperlocal as it only accepts Sysmä businesses and not for example, those in geographically close Hartola, which Sysmä shares some things with, such as the Lutheran church parish, a local newspaper, and some governance.

In the context of community currency initiatives, the sysmä has numerous distinct features, making it something of an outlier case amongst other European schemes. These features include, first, a very small population basis. Typically, the population of a geographically defined community currency area is counted in hundreds of thousands, and even rural initiatives are often based on a larger base of potential users. A village like Sysmä is akin to a large employer or a special community such as a hospital or a university. Population demographics could also be significant in the sense in which e.g., the Japanese system of Fureai Kippu (caring relationship ticket) (Hayashi, 2012; Kennedy, 2012) is targeted particularly for the elderly, yet Sysmä has been very clear to avoid the identity of an old people's service. The realities of the rural setting also include the available goods and services to be traded within the scheme, as the main businesses are agricultural, or tourism based. The food and farming sectors traditionally are lower in innovation and lower value. There is some higher value development of a Sysmä breakfast cereal and own label products that make use of terroir in the region e.g. Sahti, a local alcoholic beverage.

Yet the small population is hardly the only noteworthy demographic characteristic of Sysmä. Indeed, the municipality is one of the most holiday-home dense areas in the country relative to 
population, and the holiday season sees the population of Sysmä swell. These holiday residents are not strictly speaking Sysmä locals, but nevertheless as alternative home owners spend long periods of time regularly in the region and have something of a semi-resident identity. In addition, given the heavy urban migration from the area, there is a wider Sysmä settlement diaspora mostly living in the Helsinki-region. All in all, the number of people who could be potential community currency users, is considerably larger than the actual population base. Interestingly, there are hardly examples of a community currency established in a comparable demographic setting. Rather, other existing schemes can better classify potential users in the categories of residents and tourists.

Secondly, while the sysmä has been developed through establishing relations with civil society and partially integrated local entrepreneurs organically to the planning process, the fact remains that the evolution of the system was project-driven rather than civil society-driven, again in sharp contrast to comparable schemes. Thus, long-term management of the project is in doubt (PHL, 2019). At some point, the governance aspect must be transferred either to a company, NGO or designated part of the council of Sysmä. Making the currency a regional currency and thus supported logistically and financially is another possibility. As a tourist currency, it would make a lot of sense and lessons from the UK's Lake District Pound could be applied to this region.

It seems that the connections to other community currency schemes and user communities were few and sporadic. Yet some connections were made with the Finnish Social Forum and the Helsinki timebank (Laamanen and others, 2015). Suomen Talousdemokratia ry (Economic Democracy Finland ry), an alternative currency activist minded NGO was involved to some extent to give advice, but their expertise is not rural regeneration, local governance nor economic stimulus. There are certainly other communities in Northern Europe, which could be reached and were known by the project team, however, "When technical problems arose and the time resources of the project diminished, some contacts were abandoned to save time" (PHL, 2019, 13). There appears a low level of economic literacy around heterodox economics in Sysmä and better maintained connections could have helped shape ideas around what the money was to be used for. No university partner appears to have been meaningfully involved (Godenhjelm and Johanson, 2018) so the triple helix model of innovation which blends industry, government and university expertise was not fully benefited from.

The final report claims connections were made with: Aalto University, a recently merged university acting as an innovation fostering university; Arvotakomo, a cooperative called Valuecraft in English that "enriches local culture through alternative local, community and parallel currency experiments. The cooperative supports experiments aimed to improve economic diversity, economic sustainable development and equal economic opportunities," (Arvotakomo, 2019); VTT Oulu, a government owned technical research centre, which supports innovation; and the researchers Paulo Melo, with a sharing economy academic interest at the Faculty of Economics of the University of Coimbra, Portugal (Melo and Jorge, 2015); and Nikolay Kryachkov, who is interested in "the knowledge person" and is connected with the Russian Academy of Sciences, (Kryachkov, 2014) (PHL, 2019, 12), with additionally some who contacted the project, but were not got back to.

Thirdly, sysmä was chosen from the beginning to operate only as virtual currency. Actual coins or pre-printed banknotes were avoided at the design stage. The focus has then been on electronic transactions, which are made by computer or by mobile phone. However, afterthoughts about the mechanisms for actual use meant that your "own design" and your own note could be printed by potential users. These print-offs, which could be made at home or at one of the exchange points could have whatever design was wanted, so long as the Quick Response (QR) code (Walsh, 2009) was present and readable by a hand scanner, which was provided to retailers accepting the sysmä.

This approach seems to have been founded on the thinking of a card rather than cash-based society. This decision raises several questions and obstacles in the implementation of the scheme. This includes unforeseen technical problems, as the original devices retailers had would not scan the QR-codes properly and new devices had to be provided, which also led to the need to train workers to use these devices. Attempts by the principal researcher to use 
the printed QR-codes revealed that staff training was inadequate on half the attempts, resulting in lengthy purchase times of about five minutes. Further, the QR-code system, which does not allow either giving change or paying the exact sum from an account, would commonly result in a balance being left after using the sysmä. E.g., a typical exchange made from twenty euro for twenty sysmä upon spending those sysmä to buy goods of only eighteen sysmä would leave a balance of two sysmä. That balance had to be written on the paper note as no change was given in euro. This meant small amounts could hang around in a supposedly paper-free cashless world. This would actually lead to more paper to carry about.

\section{Tensions over purposes}

Purposively, it is hard to say what exactly the currency is supposed to achieve. Little evidence was found that the design and implementation of the sysmä was made with a co-creative process involving stakeholders and actants, which would build a participative ownership culture. Rather, it was a "they" or "we've [the Sysmä entrepreneurs association] been thinking some kind of cards or something and how to get it ... and then Juri [the project manager] went to the Päijät-Hämeen Liitto and they decide to make it money and then Juri came back and to Sysmä and told that we can make our own money". So a medium level of citizen participation, perhaps informing and cosmetic consultation, which are only tokenism, according to Arnstein's Ladder of Citizen Participation (Arnstein, 1969).

For these people, the currency has no purpose, they are indifferent toward it and do not care to learn how to use it. There does seem to be the impression that the sysmä was introduced because "we have to do something" to counter the rural decline and structural effects of poor national governance.

Rather than a parallel currency, which may counter cyclical boom and bust, the use to counter long term decline is an innovative idea for introduction of a community currency. But the identification of the problem, disaggregation and development of solutions as a strategy for rural regeneration or resilience, which the currency can be clearly linked to seems to be missing. The gap in rural policy is not a matter for this paper, though the currency could fit in with appropriately developed policies or at least facilitate social innovation (Ludvig and others, 2018). Rather than the purpose of the currency, the current focus can be described.

In Sysmä, it can be seen that the idea of mutual help predominates (Paterson, 2010) rather than full economic development or a fully evolved purpose such as rural regeneration (this is hoped for rather than planned for in the currency design), localisation or ecological sustainability are not thought of as the purposes of the sysmä. Nevertheless, individuals in Sysmä were aware that these things were important, and some connected to the project did see that the sysmä "could be so much more" and that they were only scratching the surface.

The currency has acted as a tool for increasing the visibility of the municipality via use of integrated marketing communications (Schultz and others, 1993). Indeed, portraying Sysmä as an interesting place to visit through national media could be seen as the primary function of the local currency scheme. The advocacy for rural development has been weaker, though there is an element of that story in the narratives around the currency. There is a difficulty in such a narrative - by admitting an area needs improvement it gives the perception that the area is troubled and those who are proud of a rural area often do not want to admit there is a problem.

The question about purpose of the scheme is further complicated by the above-mentioned choice not to include any physical currency. Some people wanted a tourist souvenir, but there were no beautiful notes for them to obtain and save nor for them to gift to others such as children - this usage was even promoted and at least one customer was seen trying to get such a note at an exchange point. The electronic use of sysmä as a phone-based transaction might have worked well if people had taken up this possibility. However, there were challenges with this option. Principally, this came down to a lack of trust. Some did not trust this new unfamiliar method with money. There were some technical problems where initial exchanges paid for in euro which after payment from a euro account did not appear in people's electronic accounts as sysmä. There was a lack of understanding how this phone-based use could benefit an individual who already had euro. There were also some religious objections to the idea of numbers and an electronic 
society which translated into abstention from using an electronic currency, based on interpretations of Christian teachings (Albrecht and McIntyre, 2006).

\section{Stakeholders}

In respect to the sysmä currency, there are key players and organisations in which they participate. These actants, with potentially different ideas of the desirability, purpose and design of the currency, include the mayor, project manager, city council, the local association of entrepreneurs (Sysmän Yrittäjät ry), local associations, the regional council, the provider of the technological platform, and finally the residents and other people with regular connections to Sysmä.

The local mayor is in a position of influence and is directive enough in her leadership style that she has supported the currency and successfully advocated for some of the features in its design. The project manager has led the local currency as a project, managing the budget and has experience in local government and an appropriate university qualification. They meet regularly with an advisory body that the mayor has created to discuss initiatives and ideas called the Elinvoimatyöryhmä (Vitality Working Group). This working-group is not directly elected and has no direct electoral power. It includes some council workers, business people and may invite others to give evidence and is consulted by the mayor, who uses its advice to make decisions. The municipal council, even though not de facto independent from the mayor and the project manager, has formally the power over the eligibility criteria of the currency scheme, in other words over who can issue the money.

The local entrepreneurs association members were thought of as the main users and beneficiaries of the community currency. However, they did not decide on this and did not provide any funding. It was presented to them in a 'this is what "we" will do way', rather than co-created with the association as a whole. Yet, the business sector has interacted with the government sector via a committee for innovation / renovation. This committee originally approached the Päijät-Häme regional council for regional funding for the loyalty card. However, a card scheme was felt not to be innovative enough by the time an approach was made to the regional council. The regional council said instead there was funding for creating a local currency. This made the regional council a key player in the scheme as a co-initiator and the body with control to innovation funds. Practically, the form and perceived purpose of the currency were partially shaped by the fact that the funding, which initially enabled the scheme came from regional council innovation funds.

The funding was as follows: AIKO 38,556 euro and Sysmä Municipality 16,524 euro (PHL, 2017). AIKO (Regional innovations and experiments in the regions) gave funding for regional development and operated under a regional development paradigm. It followed the Act on the Financing of Regional Development and Structural Fund Projects (8/2014) (PHL, 2017). Specifically, this project purpose was described, thus "Sysmä municipality will put into circulation euro-vouchers and place the amount of euro in safe store corresponding to the value of eurovouchers to be issued and to guarantee the value of the voucher. Euro-vouchers will be widely marketed, and efforts made to get as many Sysmän entrepreneurships and associations as possible to accept them into use. Entrepreneurships will be incentivized to pay with eurovouchers. During the pilot, Sysmä municipality will make small purchases with euro-vouchers. The pilot will create a network for small entrepreneurs to cooperatively submit and plan mutual offers." (PHL, 2017).

\footnotetext{
7 “Sysmän kunta laskee liikkeelle kuponkieuroja ja sijoittaa liikkeelle laskettavien kuponkieurojen määrää vastaavan määrän euroja turvalliseen sijoituskohteeseen sekä takaa kuponkieuron arvon. Kuponkieuroja markkinoidaan laajasti sekä pyritään saamaan mahdollisimman moni sysmäläinen yritys ja yhdistys hyväksymään ne käyttöön. Yrityksiä kannustetaan maksamaan kuponkieuroilla. Sysmän kunta tekee pilotin aikana pienhankinnat kuponkieuroina. Pilotissa luodaan verkosto pienyrittäjille yhteisten tarjousten jättämiseen ja suunnittelua varten." NB Finnish uses etusetili (bounty note) for voucher, but here the common word of kuponki is used, though the meaning is a voucher in English and not a coupon. The nuance being the greater fungibility of vouchers than coupons. Similarly, "sijoituskohteeseen" (set aside) does not specify if this is: ringfenced, and so controlled by the municipality; or if it is in escrow, and thus held by a third party.
} 
There were also some hard targets, which were, increased local businesses of 5 (in effect none were created) and 10 jobs created (in effect none were created) (PHL, 2019, 20).

Once it was agreed to have the currency, a promotion budget was agreed and technical services for supporting the currency were to be provided by Arantio Oy (Oy translates as Ltd, limited company). Arantio has an expertise in gym and luncheon voucher systems for business customers. It is not physically located in Sysmä. However, the scheme is technically dependent on the company, which makes the company a stakeholder in the scheme. Further, technical support and operating the main exchange point has been provided by a worker who is an IT repair specialist, practically as a volunteer input. In the long term, it is not clear who will adopt this role.

There has been little consultation of the Sysmä society, with an apparently paternalistic rather than participative method of governance. Despite aims to engage the locals, not many did, for instance, claim their five free sysmäs, which were available for all residents as "helicopter money". This idea is commonly found with the marketing of crypto currencies and is called an "airdrop" (Alassouli, 2018). The diaspora has been only a little bit involved in the community management through an association called the Sysmän neuvottelukunta (Sysmä rural community council) ${ }^{8}$, which meets twice a year and has a University of Cambridge professor amongst its active, invite only membership.

This is now changing and the diaspora might be the future to look at. As there are four times the population with alternative homes in Sysmä than permanent residents, then targeting the alternative homeowner population as a market segment makes some sense. This is now happening with a planned for e-residency initiative, which seems influenced by a similar scheme in Estonia (Roots and Dumbrava, 2016). Such an initiative could act well in identity forming of alternative homeowners to regard themselves as a Sysmä diaspora, much in the way that longterm residents gradually adopt their place of destination rather than place of origin as their placebased identity through social construction (Sampson and Goodrich, 2009).

A question related to identifying the stakeholders is the identification of potential beneficiaries. As the municipal council has the power to decide on the criteria, it thus determines which businesses are accepted and benefit from the scheme. Practically, this has led to exclusion of some local businesses and divided the business community. While the hyperlocality of the scheme draws its justification from the very idea of local currency, many clearly local but non-locally registered businesses are left out. An example is the Sysmän Kirjakaupa (Sysmä's Bookstore) which is a small business that has been very supportive of the connections that have made the Kirjakyläpäivät viable in Sysmä (Seaton, 1999), it supports a local book association's events and even hosted the main sysmä exchange point in its building. Yet despite the owner wanting to participate, she cannot as the business is not registered in Sysmä, but in another municipality in the region. A different governance structure might have allowed the bookstore to participate. In practice, the project is run in a friendly way and while only given businesses are allowed to cashin sysmä for euro for a small redemption fee, the main exchange point has changed back individuals' sysmä for euro as a goodwill gesture, despite regulations.

At the same time, the council decided to issue local community support in sysmä. It has done this in a divisive way, which shows it has power over the local community. The Road Communities (who are responsible for keeping the local roads passable) and local associations have suffered because of the decision to only pay them this year's grants in sysmä. The decision was made after the financial year had begun and they had already made commitments with suppliers to pay them in euro. Some of the services and goods they need to buy are not available from anyone who will accept sysmä. Many supporters of the idea of sysmä have been unable and unwilling to defend the way this decision was carried out. Ironically, these communities and associations have made up the majority of exchanges as payment transfers from the municipality (PHL, 2019, 10).

\footnotetext{
${ }^{8} \mathrm{NB}$ the term rural community council has been used for the equivalent body in the UK, though usage is moving away from this due to confusion with elected representational bodies. The term advisory board might be an alternative. Powers and constitutions vary between boards, advisory boards, authorities, councils, administrative councils, committees and working groups. This reveals a tension between "efficiency" and "democracy", see (Pleschberger 2003, 113) for discussion on this.
} 
The council itself has come across as hypocritical as it has forced local associations to take the sysmä while some of its own schemes have not required the sysmä, such as a paid work experience scheme for young people working in the municipality and at some local businesses. This can be interpreted as non-transparent governance, yet fundamentally, it reflects the projectdriven rather than civil society-driven origin of the scheme. Due to dissatisfaction with the way politics has been recently conducted, a new political party has appeared to try and challenge the way politics is done in Sysmä. This new party formation is not attributable to the Sysmä Money Project, although it contains within it some of the troublesome political praxis of small groups acting in a quasi-open way. This means that the community currency could easily be seen as a partisan project rather than something the whole community has ownership of and is indicative of aspects of stakeholder inclusion, which can prove crucial in a public service innovation context (Godenhjelm and Johanson, 2018). According to the project application, the stakeholders should have been: Sysmän Yrittäjät (Sysmä entrepreneurs association), Sysmän 4H (Sysmä 4H - a rural youth organization), Sysmäläisiä yrityksiä (Sysmä people who were entrepreneurs), Sysmäläisiä yhdistyksiä (Sysmä associations), Vapaa-ajan neuvottelukunta SNK (Sysmä Community Council) and Kunnan hallintokunnat (the municipality board) (Simola, 2017). In praxis, key stakeholders were only marginally involved, notably the associations and community council.

\section{Marketing, technology and future viability}

The funding of the sysmä money has been possible due to regional innovation money, and money from the municipal budget (Talasterä and Sources, 2017). However, such money will not be available for future years and so the Sysmä municipality (or some other entity) will have to provide some financial support. Long-term, the money invested must break even or at least generate economic benefits to make it worth continuing. There is a question as to if one village can do this, or if it should expand to other communities or even exist as a regional currency. This would work in similar numbers to a currency like the Brixton Pound (Hileman, 2014). Nevertheless, return on investment is not simple to calculate as the figures for the technical and logistical sides of the currency are only part of the costs, and some returns might be incommensurable with the investments.

Communication marketing must also be considered. Information about the currency disseminated through national media with articles in the press (PHL, 2019,9) and attendance at conferences where the currency was discussed (PHL, 2019, 3-4). Yet, the idea was the currency would be used by local businesses. The local population seems poorly engaged, particularly in comparison to the non-local publicity.

The marketing mix, understood as integrated marketing communications (Schultz and others, 1993), was not developed with good points of sale, booklets or other promotional materials within a properly applied marketing plan. Posters and stickers were made, but they were not optimally installed, even by those participating entrepreneurs that took the materials. There was also a lack of related merchandise that people might adopt, for example, cups, T-shirts or phone covers. In contrast, the website was a functioning way to promote the currency with an implication that there was a social media strategy behind it.

The currency (or as the currency is a digital currency, the digital image or printed out papers with QR-codes on them, that can be scanned for payments and theoretically could function as currency which were available at some locations) itself is not pretty and has been described as "ugly" in contrast to the last set of markka (Finland's national pre-euro currency), which was liked as it showed-off Finnish culture and luminaries. Due to technical problems with the sysmä back end, the introduction was impeded and thus the initial promotion of the sysmä ended up being done too early. There was thus a lot of promotion of the sysmä and then people were unable to use it and obtain it. As a result, viral and guerrilla marketing were not possible and instead the business community itself avoided marketing what was described as a "clown shoe operation".

However, there were good promotional ideas. The local produce company Rantala made a slick video showing children using the sysmä money which showed how easy it was. A discount was offered for the money, where a five per cent bonus was paid for those exchanging a certain amount of euro for sysmä. Lastly, there was a giveaway for all Sysmä residents of five sysmä 
which could be spent with any participating retailer or entrepreneur $(n \sim 30)(P H L, 2019,10)$. One of the businesses, Camping Sysmä, offered a special promotion as a result of this fiver giveaway.

More broadly when considering the wider aspects of the marketing mix (Schultz and others, 1993), there seemed little obvious conscious thought on how these elements were to be developed. Product was not evaluated well from the consumer perspective, instead it was led by an interpretation of wants of the business community. There was no baseline survey done for either of these stakeholder groups. Price was considered with a low financial cost for uptake by consumers, but the wider costs of adopting and using the sysmä were poorly catered for. Place was considered to some extent with an office, web-presence and materials to promote points of sale made and distributed, though cross-branding and mounting of promotional materials was poorly achieved. Process and people did not seem to have been considered to a great depth and there seemed a reactive ad hoc response to the needs for training rather than a proactive one. People did not seem to have had associated customer service training, nor buy-in to sysmä as a thing they could engage with.

Technology transfer would be a good way of approaching the sysmä money. There have been around 4,000 community currencies in the last century or so, with notable successes in Scandinavia (Conaty and Lewis, 2012). To see how they have worked or how other communitybased IT projects have worked allows a comparative study of the sysmä case to be undertaken. With a rural innovation, there are particular challenges that arise, which do not affect urban innovations mostly related to socio-geographical aspects (Lee, 1996; North, 2005). There are challenges with any innovation that a description of what happened does not mean that successes and failures could have been assured or avoided respectfully. Rather, a culture of failure management is a measure of success, which can judge final outcomes after a process, has been completed.

Arantio Oy, the company that was to provide the technical support, devices and software for the sysmä, has not been as responsive in time and fixing as was expected so that it "was unable to provide the information that was promised" (PHL, 2019, 10). Serious technical problems arose that the sysmä system was not functioning at crucial moments (PHL, 2019, 7-8). The project management of the technical side was not done in concert with the promotional side well enough to avoid wasting money on wrongly timed marketing and staff time. There was a mission critical fault when money could not be exchanged back into euro from sysmä, which meant a cash flow problem for businesses could arise. During this time, the project manager at Arantio Oy went on holiday and could not be reached. As there was no back-up mechanism, this was a disaster for the staff trying to promote the sysmä.

Another technical problem with non-scanning meant that devices had to be provided to all the participants that needed them. However, this problem appears it was sorted out in a timely way. While people understand on an intellectual level that problems may arise, the user community of businesses were poorly prepared for potential problems that may arise within the innovation process and lost confidence in the project. Better education could have come from both Arantio Oy and the project team about this possibility.

The use of phones as a way of using the currency was an innovation that it seemed would work well based on the buzz around electronic currencies and moves to a cashless society (Ngugi and others, 2010; Wolman, 2013). However, there was no market analysis and investigation if these were real trends or the media hype which new technology attracts (Levy, 2015). There appeared to be neither baseline study nor market research done on the potential users of the money. The idea that businesses would use the currency was an aspiration that the business community did not hold. As most of the businesses members of Sysmän Yrittäjät ry already had a system of account with each other, the sysmä was not seen as useful to them as a service. The diaspora and ordinary people of Sysmä who it was hoped would use the sysmä were not asked nor trialled with sub-populations. The lack of social science or market research meant investment and development of the phone-side was done, when it appears other aspects were neglected. 


\section{Discussion}

The description above described the launching stage of the sysmä currency. Generationally, the currency can indeed be described as in the trial or experimental phase (contrast with a product introduction or a new business). This is noteworthy for two reasons. Firstly, the currency scheme might still develop by learning from past mistakes, as it matures through the trial phase. Secondly, the evaluation of the trial phase shows that as far as the cultural evolution in respect to community currencies is still to take place in the Finnish society, the structures of governance need to adjust in order to accommodate schemes like the sysmä with ease. The sysmä might be described as a fitting in with the "fourth generation of complementary currency systems" due both to the partnerships with local authorities and others in combination with being electronic money (Fare and Ahmed, 2017b).

In the sysmä case, most pressing problems relate to governance and technology. The currency has limited uptake due to technical issues, injudicious application of the marketing mix and difficulties with innovating in a rural area (Dower, 2013; North and Smallbone, 2006). Political decisions over limiting rights of issuance of sysmä to locally registered businesses; and its exclusive use for local association subsidies given by the municipality have created some challenges to the acceptance of the sysmä. Launching the scheme was carried out as a top-down implementation using a project management methodology.

The decision to rely on QR-codes as currency as a wise one can be contested. The design choices of the currency features for a rural area can be seen as an issue. But a deeper analysis reveals that there are several related aspects to this in terms of convenience and familiarity. Adoption of a digital local currency relies on "previous experience" (Giménez and Tamajón, 2019), which in the case of a new initiative can be regarded in economic terms as continuity over a substitute good for fiat currency (Nechyba, 2016). These QR codes are not a perfect substitute and could be said to be a cross-category substitution. There are examples of such cross-category substitution being launched in the last few years without an intermediary step of paper based local currency notes. Colu, an Israeli firm, has successfully introduced The Liverpool Pound, for example, based on a mobile phone app (Koenig, 2017). The Kintetsu Group has experimented with the Harukas Coin with participants selected from members of its KIPS loyalty card scheme in Japan (Kintetsu, 2018), which operates as a virtual currency.

In the case of the sysmä, the argument can be made that the Finnish consumer and business is already familiar with card-based loyalty cards that give points e.g., Plussa-Kortti (Kesko, 2016), S-Etukortti (S Group 2019). The K-Plussa loyalty system has already been offering "digital Plussa money" and the possibility to pay with a mobile-phone based app called the K-Plussa-mobiilikortti at least since 2017 (Kesko, 2019; K-rhymä, 2017). The market penetration of mobile phones and the K-Plussa cards is very high in Finland, with $79 \%$ of the population in total and around $50 \%$ of pensioners using smart phones in 2017 (SF 2019) and 2.2 million (Kesko, 2016) of the 2.7 million households (OSF 2019) holding Plussa cards. It was reasonable to expect there was a large enough potential pool of early adopters for a digital local currency in Sysmä without the need for a paper-based currency. In economic terms, there was sufficient elasticity of substitution to meet the continuity taste requirements of users switching to use the sysmä, while maintaining their utility with the essential good of a functioning currency.

Greco convincingly argues that local currencies can be divided into two forms; "a ledger of accounts to keep track of exchanges, and local currency systems ... which use circulating paper notes to give people a way of tracking their exchanges" (Greco, 2001, 183). Thus, in the case of the sysmä, which is a system of account, it has perhaps more in common with the ledger form. Such ledger forms have no paper notes and have in some cases gone straight to digital. This is increasingly so nigh on 2 decades after Greco was writing, as fourth generation community currencies money (Fare and Ahmed, 2017b) and ubiquitous computing (Greenfield, 2010) have changed the sphere and rules in which community currencies can effectively operate.

An example of straight to digital is Freecoin that has been set up by the Dyne.org Foundation as a social digital currency set of tools and has some working examples in Italy, Croatia and the Netherlands (Sachy, 2017). The Cyclos software provides a backend to support a wide range of community currency and related initiatives (Valek and Bures, 2019), for example, the Hudson 
Current which started and has only operated digitally (McCarthy and Reidelbach, 2016). Other new digital currency initiatives are often hyped as altcoins or linked with blockchain or holochain - even when in fact they are not. For example, "sysmäCoin" was used to refer to the sysmä, even though it was not an Altcoin.

Though we argue, in design terms that for the sysmä, there was no path dependent lock-in (Liebowitz and Margolis, 1999) necessitating a physical currency first, we do argue that in this case, producing circulating paper notes would have been a prudent move. It would have allowed tourists to exchange hard cash for the notes, built familiarity and acceptance in the local population and been an effective marketing tool. Nevertheless, merely producing the notes would not have assured the success of the sysmä, in addition local economic literacy efforts such as cocreative processes or workshops would have made success more likely as has been found elsewhere (Blanc and Fare, 2012). These would have acted to engage in market education and overcome innovation resistance (Ram and Sheth, 1989).

On the other hand, the scheme has had good press coverage, locally, regionally and nationally and even some internationally (PHL, 2019, 9). Users have benefited from discount incentives and the possibility to pay water bills with the currency. Having the possibility to pay such a widely used utility is a strong factor in building acceptance and thus a successful currency (Greco, 2009).

Low volume of sysmä means the currency has insignificantly transacted. The final report said under 200,000 euro, but our estimate is around 100,000 euro based on the claim of 20,000 tax take from transactions (PHL, 2019, 20). Local businesses are ostensibly the focus, with the idea that they benefit from the sysmä. How they would benefit is not clear. Most of the businesses already have a system of account with other local businesses, so this does not serve them. Some community benefit accrues as those exchanging euro for the sysmä are limited in where they can spend it - so it must be spent in the businesses which are part of the scheme. Most of the individual spends have been in the Suvituuli Supermarket; so good as a subsidy for the owner of that business, and she is inordinately supportive of locally sourced goods, with an aisle deliberately stocked with many local products. So this has the potential to stimulate the local economy. Another beneficiary could be the municipality, ironically due to the administration of the scheme, as the local road communities and associations that get grants for carrying out their work have been paid in sysmä. As it is difficult for them to spend these sysmä, it may be that there is a saving for the municipality. At least one large non-municipality transaction of 15,000 euro took place, and so there must have been a clear business case for that transaction. This has benefited from a five per cent incentive built into the scheme.

Another part of the equation is the community of interest or usage for any community currency and their concomitant social relations (Lee and others, 2004). In this case, the community of potential usage and community of actual usage can be separated into sectors or cohorts. A sectoral approach would consider the second sector or business community, the governance, or first sector and the third sector or community organisations. A cohort approach would consider users such as the residents and workers in Sysmä; alternative home owners; tourists and business people / owners. This approach can look at the burden and the benefits to each cohort or sector. Good governance and thinking about the currency implication and where and how it can be used can ensure users benefit from its introduction. The terms market segment and actant are other labels that can be used rather than cohort or sector with each being associated with different theoretical connotations.

Products and services traditionally go through a life-cycle. This life-cycle is mediated by wider trends in society. However, despite a path dependency shaping how innovations will manifest and be diffused, there needs to be a novel element to them for them to gain a niche-hold within the consumerist culture that dominates most human societies (Heiler, 2008; Libery and Kneafsey, 1998). There also needs to be a driver for innovation. The innovation driver in Sysmä is the rural decline and changing demographics of a rural area. Or rather, the decline spurs some people to react against the changes not to regress to nostalgia, but towards a more creative destruction response of social innovation (Ludvig and others, 2018). That process is an ongoing process and innovations are developing within this matrix. 
Recently, this concept of the brand of Sysmä has started to crystalise in people's minds. The idea of Sysmä as an innovative centre that shows the world how to be - a kind of Sysmä pride - ties in with value systems found in Nordic rural communities (Halhead, 2006). This is creating a pull factor and makes Sysmä interesting to people that can now see it not only as a rural dead-end backwater.

With flexible part-time and changing working landscapes, the concept of a job and then retirement is being eroded and the potential to be working and being in different places over time is increasing. As a result, it does not make sense to see living in Sysmä as being a holiday or a second home and being somewhere else as the primary home. A new way of seeing things is to speak of alternative homes. At present, the Finnish legal requirements do allow people to register as being in the country with no fixed municipality, but strongly encourage registration to only one municipality. There is currently a discussion about people being able to register in two places for specific times of the year - a summer and winter registration.

If Sysmä is to follow this path, it may have to accept that the population profile is drastically different and not a place with many lapsiperhe (families with children) and a resultant change in service provision. The idea of Sysmä is also changing. It may become a culture and a place where many people will feel an affinity with who may not be geographically present a lot of the time. As a post-agrarian and now post-industrial community, how does it look in a rural community that is not tied to the land or industry for its identity? Instead, an identity might be centred around cultural icons. A potential cultural icon can be the sysmä money, what it can be used for, along with the effects it has on the community and the wider diaspora.

It is possible to pay the water bill in sysmä, the mayor of the city has talked about receiving a third of her salary in sysmä (the Mayor of Bristol gets all his salary in Bristol pounds) and members of the project team say "there is so much more" that the currency could do and be used for. If that wider internal diaspora is to be reached and created in identity, there are several processes that must be undergone. Identity building comes from a shared culture, this can be through associations, and common experiences. Can the sysmä currency serve the diaspora? The e-government approach is being rolled out for service access. There is an idea to allow health-care services with a large private provider to develop that service provision. The same aspect of paying in sysmä also works if people are persuaded to exchange their euro for sysmä.

Conversion from euro to sysmä can be trivial, as in the case of wanting to buy an ice-cream with sysmä for children to have the excitement of using different money. But a community currency is the beginning of economic literacy. The idea of money or currency or economics can be more broadly thought of when people start to consider, as anthropologists do when they think of exchange, as more than just market exchange (Eriksen, 2001), and that there is a homo reciprocans approach with broader sustainability questions (Lake, 2010) and transitioning society or relations that are part of any transaction beyond the neo-classical synthesis embodied in the homunculus homo economicus. This approach shows that a wider usage of the sysmä by the diaspora is possible.

A community currency for the Sysmä diaspora may lead to holiday cash with an increased local and regional spending; a savings account, which allows Sysmä as a community to invest the generated wealth locally and even to develop other purposes. The community currency could be used for rural regeneration and economic and social inclusion. Sysmä can be used for a Fureai Kippu (Hayashi, 2012) type scheme to support older people, educational or youth money. There is also a potential to grow the economy by producing non-ringfenced money that moves transactions in time for economic security or as a counter cyclical measure.

If there is sufficient market capitalisation, it may be that the money can be used to generate a regional regeneration, or a rural renaissance. Such a process may be utopian and lead to counter-urbanisation with an increasing population and greater services. Counter-urbanisation has been conceived of under an old paradigm of people only living in one location as a primary residence. Counter-urbanisation under a dynamic of digital ubiquity (Greenfield, 2010) and of alternative homes might involve the shifting of resources without the geographical shifting of people at the same scale. There is evidence of this happening when looking at the investments in altcoins that are not physically located anywhere. These desires and ideas are certainly 
the hopes of many. They are also seen by some as the answer to the great shift we must make for climate change mitigation and adaptation in this century. They take somewhat of a futurist perspective and there are counter narratives which see the opposite happening with a loss and eventual death of the rural, no matter what is tried.

Examples and elements of the more hopeful narrative can be found as experimental projects around the world. The involvement of diasporas in remittances for developments, both within a country (Skeldon, 1997) and between countries (Gorchakova, 2012), has been well demonstrated (Constant and Zimmermann, 2016). For the area of Sysmä, which is in Finland, which is a rich well-developed country, this has not been shown. There is at present some transfer of wealth from the diaspora to Sysmä using the conventional money system. Property taxes are paid, some services are purchased from local businesses. However, for the sysmä to play a role, there needs to be a better economic mapping to see where the spending is now and where it potentially could be shifted towards the sysmä currency and thence benefit the Sysmä area.

\section{Conclusion}

Sysmä's experiment has lessons for other communities facing similar societal shifts across the Nordic Region (Grunfelder, 2018). As ever, the implementation of an idea is a key factor in whether it is successful or not. The sysmä has proven that a rural community can be financed sufficiently to set-up and run a hyper-local community currency scheme. However, the reliance on the commercial sector to provide the solutions for development of a disruptive innovation in a rural community is in doubt. The project manager ascribes part of the failure as based on the diffusion theory of innovation (Rogers, 2010), namely not engaging enough early adopters who were "local adopters" (PHL, 2019, 16), yet this lacks an understanding of disruptive innovation. A disruptive innovation by its very experimental idea is a prototype and not well adapted for the market, rather it shows how a product or service could be so adapted (Chatterjee, 2009). From this perspective, lessons from the sysmä might well show a success even if the individual prototype is not the final successful form hoped for.

There was an industry partner, but it was not an enthusiastic champion of the idea throughout the project. Knowledge capital was available in limited amounts, with no benchmarking or twinning with other analogous projects whereby experiential learning for capacity building might have been obtained at low cost. Rural innovations have proven successful in the past by bringing in different expertise, for example, in the triple helix concept with (industry, government and academia) (Haas and others, 2016; Triple Helix Research Group 2013) with a university or even with living labs or other actants as partners in what is labelled the Quadruple Helix (Arnkil and others, 2010; Leydesdorff, 2012).

It appears in this case there is a lack of strategic planning. A strategic plan which would have not merely hoped the currency would be successful, but would have considered how or where it might develop if it was to be successful was lacking. The various capitals that needed to be mobilised to support the sysmä were not coherently planned and contracted for. Financial capital was provided by the regional innovation fund and the municipality, and some resources were provided by the entrepreneurs that participated. Yet, it appears the money was used as seed capital without considering how a financing stream would be maintained after launch (PHL, 2019, 18). An initial plan of half a year is perhaps not the three or four years which would be needed to properly establish the sysmä system.

This community currency is strictly a system of account, and not properly a currency as it does not circulate as a currency should. It faced a challenge in the evolutionary competition of financial systems in occupying a niche, as the local entrepreneurs already had a system of account they were using. If they had lacked such a system, it is possible the sysmä would have been the system they would have adopted as there would have been a business case / use for it. Similarly, while local firebrands may support a currency, there also needs an element of local cultural capital, which is supportive of the currency. In Sysmä's case, this was seriously eroded by an organisational core culture (Schneider, 1994) that was a control and command culture rather than a collaboration culture within which the project and people would have worked together to successfully co-create a working economic system using the sysmä. 
A community currency can be introduced to any environment, but the trajectory of cultural evolution must at least be worked with synergistically if it is to stand a chance of establishment in that community. The receptiveness to innovation can vary significantly between superficially similar communities (Rogers, 2010). It remains a moot point as to if there is a vortex of decline in rural communities from the institutional factors acting in a syndemic way, with such momentum that rural renewal via a complementary currency is made impossible by insufficient resilience capacity in the system. Attempting to arrest long-term rural decline and to engage successfully in counter-urbanisation requires a certain capacity in terms of various capitals. It appears that this community currency on its own did not provide enough capacity to accomplish the art of the possible.

\section{Academic references}

[1] Alassouli, H. M. (2018). Internet Earning Through Cryptocurrency Airdrops, Bounties, Cloud Mining and Investment Websites. Morrisville NC: Lulu.com.

[2] Albrecht, K. \& McIntyre, L. (2006). The Spychips Threat: Why Christians Should Resist RFID and Electronic Surveillance. Nashville, TN: Thomas Nelson Inc. DOI: 10.1197/jamia.M2339.

[3] Aldridge, T. J., Patterson, A. \& Tooke, J. (2003). Trading Places: geography and the role of Local Exchange Trading Schemes in local sustainable development. In Buckingham, S. \& Theobald, K., eds., Local Environmental Sustainability (pp. 169-194). Boca Raton, FL: Woodhead Publishing in Environmental Management. DOI: 10.1016/b978-1-85573-6856.50011-6.

[4] Almstedt, Å. (2013). Post-productivism in rural areas: A contested concept. In Natural Resources and Regional Development Theory (pp. 8-22). Umeå universitet.

[5] Arnkil, R., Järvensivu, A., Koski, P. \& Piirainen, T. (2010). Final Report on Quadruple Helix Research for the CLIQ project, Exploring Quadruple Helix - Outlining user-oriented innovation models. Tampere: University of Tampere.

[6] Arnstein, S. R. (1969). A Ladder of Citizen Participation. Journal of the American Planning Association 35(4), 216-224. DOI: 10.1080/01944366908977225.

[7] Basit, T. (2003). Manual or electronic? The role of coding in qualitative data analysis. Educational Research, 45(2), 143-154. DOI: 10.1080/0013188032000133548.

[8] Blanc, J. (2011). Classifying "CCs": Community, complementary and local currencies' types and generations. International Journal of Community Currency Research 15D, 4-10. DOI: 10.15133/j.ijccr.2011.013.

[9] Blanc, J. \& Fare, M. (2012). Les monnaies sociales en tant que dispositifs innovants: une évaluation. Innovations - Revue d'économie et de management de l'innovation 2(38), 6784. DOI: $10.3917 /$ inno.038.0067.

[10] Brubaker, R. (2005). The 'diaspora' diaspora. Ethnic and Racial Studies 28(1), 1-19. DOI: 10.1080/0141987042000289997.

[11] Brunnhuber, S. (2015). How to Finance our Sustainable Development Goals (SDGs): Socioecological Quantitative Easing (QE) as a Parallel Currency to Make the World a Better Place. Cadmus 2(5), 112-118.

[12] Cartwright, A. (2013). Knowing when it is time to go: managing rural decline in Central and Eastern Europe. Pannon Management Review 2(1), 33-48.

[13] Champion, T. \& Hugo, G. (2003). Introduction: Moving Beyond the Urban-Rural Dichotomy. In Hugo G., ed., New forms of urbanization: beyond the urban-rural dichotomy. (pp. 3-24). London: Routledge. DOI: 10.4324/9781315248073. 
[14] Chatterjee, B. (2009). Further analysis on sustaining and disruptive technologies. In Finding the Innovation Gap: Disruptive idea, a better way of managing prototypes (Chapter 8). Bloomington IN: iUniverse.

[15] Christopherson, S., Michie, J. \& Tyler, P. (2010). Regional resilience: theoretical and empirical perspectives Cambridge Journal of Regions, Economy and Society 3(1), 3-10. DOI: $10.1093 /$ cjres/rsq004.

[16] Cloke, P. (1985). Counterurbanisation: a rural perspective. Geography 70(1), 13-23.

[17] Cohen, B. J. (1998). The Geography of Money. Ithaca, NY: Cornell University Press.

[18] Conaty, P. \& Lewis, M. (2012). Sweden's JAK Bank: Liberating Community Finance from the Ball and Chain of Compound Interest. In The Resilience Imperative - Co-operative Transitions to a Steady-state Economy (pp. 51-57). Gabriola Island BC: New Society Publishers.

[19] Constant, A. F. \& Zimmermann, K. F. (2016). Diaspora economics: New perspectives. International Journal of Manpower 37(7), 1110-1135. DOI: 10.2139/ssrn.2830927.

[20] Cumming, G. S., Barnes, G., Perz, S., Schmink, M., Sieving, K. E., Sauthworth, J., Binford, M., Halt, R. D., Stickler, C. \& van Holt, T. (2005). An exploratory framework for the empirical measurement of resilience. Ecosystems 8(8), 975-987. DOI: 10.1007/s10021-005-0129-z.

[21] de Groot, A. D. (2014). The meaning of "significance" for different types of research [translated and annotated by Wagenmakers, E-J., Borsboom, D., Verhagen, J., Kievit, R., Bakker, M., Cramer, A., Matzke, D., Mellenbergh, D. and van der Maas, H. L. J.]. Acta Psychologica, 148, 188-194. DOI: 10.1016/j.actpsy.2014.02.001.

[22] de la Rosa, J. L. \& Stodder, J. (2015). On Velocity in Several Complementary Currencies. International Journal of Community Currency Research 19(D), 114-127. DOI: 10.15133/j.ijccr.2015.012.

[23] Dower, M. (2013). Rural development in the New Paradigm. In Kolczynski, M. ed., The new paradigm in action - on successful partnerships (pp. 30-50). Warsaw: Ministry of Regional Development.

[24] Eckerberg, K. \& Forsberg, B. (1998). Implementing Agenda 21 in local government: the Swedish experience. Local Environment 3(3), 333-347. DOI: $10.1080 / 13549839808725569$.

[25] Eliadis, F. P., Hill, M. M. \& Howlett, M. (2005). Designing Government: From Instruments to Governance. Montreal QC: McGill-Queen's University Press.

[26] Eriksen, T. H. (2001). Exchange and Consumption. In Small Places, Large Issues: An Introduction to Social and Cultural Anthropology. $4^{\text {th }}$ ed., pp. 217-240. London: Pluto Press. DOI: 10.2307/j.ctt183p184.

[27] Eskelinen, T. (2018). Social Space for Self-Organising: An Exploratory Study of Timebanks in Finland and in the UK. Nordic Journal of Social Research 9, 89-109. DOI: $10.7577 /$ njsr.2148.

[28] Falk, A., PHL, 2003). Homo Oeconomicus versus Homo Reciprocans: Ansätze für ein neues Wirtschaftspolitisches Leitbild? Perspektiven der Wirtschaftspolitik 4(1), 141-172. DOI: 10.1515/1468-2516.t01-1-00011.

[29] Fare, M. \& Ahmed, P. O. (2017). Why are complementary currency systems difficult to grasp within conventional economics? Revue Interventions économiques 59, 1-20. DOI: 10.4000/interventionseconomiques.3960.

[30] Fare, M. \& Ahmed, P. O. (2017b). Complementary Currency Systems and their Ability to Support Economic and Social Changes. Development and Change 48(5), 847-872. DOI: $10.1111 /$ dech.12322. 
[31] Fieldsend, A. F. (2013). Rural Renaissance: an integral component of regional economic resilience. Studies in Agricultural Economics 115(2), 85-91. DOI: 10.7896/j.1225.

[32] Fox, D. (2008). Property Rights in Money. Oxford: Oxford University Press.

[33] Freeman, R. E. (2010). The Stakeholder Concept and Strategic Management. In Freeman, R. E., ed., Strategic Management: A Stakeholder Approach (pp. 31-51). Cambridge: Cambridge University Press. DOI: 10.1017/cbo9781139192675.005.

[34] Friedman, A. L. \& Miles, S. (2006). Stakeholders: Theory and practice. Oxford: Oxford University Press.

[35] Gelleri, C. (2009). Chiemgauer Regiomoney: Theory and Practice of a Local Currency. International Journal of Community Currency Research 13, 6175. DOI: 10.15133/j.ijccr.2009.006.

[36] Geertz, C. (2000). Available Light: Anthropological Reflections on Philosophical Topics. Princeton NJ: Princeton University Press. DOI: 10.1515/9781400823406.

[37] Giménez, A. F. C. \& Tamajón, L. G. (2019). An Analysis of the Process of Adopting Local Digital Currencies in Support of Sustainable Development. Sustainability 11(3), 849. DOI: $10.3390 /$ su11030849.

[38] Gintis, H. (2000). Beyond Homo economicus: evidence from experimental economics. Ecological Economics 35(3), 311-322. DOI: 10.1016/S0921-8009(00)00216-0.

[39] Godenhjelm, S. \& Johanson, J-E. (2018). The effect of stakeholder inclusion on public sector project innovation. International Review of Administrative Sciences 84(1), 42-62. DOI: $10.1177 / 0020852315620291$.

[40] Goodman, L. A. (1961). Snowball Sampling. The Annals of Mathematical Statistics 32(1), 148-170. DOI: $10.1214 /$ aoms/1177705148.

[41] Gorchakova, N. (2012). Conceptualisation of transnational remittances as social capital (re) production. The case of the Somali diaspora in Finland. [Master Thesis]. University of Helsinki.

[42] Greco, T. (2001). Improving Local Currencies, or How To Make a Good Thing Better. In Money: Understanding and Creating Alternatives to Legal Tender (pp. 181-196). White River Junction VT: Chelsea Green Publishing.

[43] Greco, T. (2009). How Complementary Currencies Succeed or Fail. In The End of Money and the Future of Civilization (pp. 144-159). White River Junction VT: Chelsea Green Publishing.

[44] Greco, T. (2012). Reclaiming the credit commons: Towards a butterfly society. In Bolier, D. \& Helfrich, S., eds., The Wealth of the Commons: A World Beyond Market \& State, pp. 230 5. Amerherst MA: Levellers Press.

[45] Greenfield, A. (2010). Everyware: The Dawning Age of Ubiquitous Computing. Berkeley CA: Pearson Education.

[46] Grüne-Yanoff, T. (2012). Paradoxes of Rational Choice Theory. In Roeser, S., Hillerbrand, R., Sandin, P. \& Peterson, M., eds., Handbook of Risk Theory (pp. 499-516). Dordrecht: Springer. DOI: 10.1007/978-94-007-1433-5_19.

[47] Grunfelder, J., Rispling, L. \& Norlén, G. (2018). State of the Nordic Region 2018. Stockholm: NORDREGIO. DOI: 10.6027/nord2018-001.

[48] Gubrium, J. F., Holstein, J. A., Marvasti, A. B. \& McKinney, K. D. et al. (2012). The SAGE Handbook of Interview Research: The Complexity of the Craft. $2^{\text {nd }}$ ed. Thousand Oaks: Sage Publications. DOI: 10.4135/9781452218403.

[49] Haas, R., Meixner, O. \& Petz, M. (2016). Enabling community-powered co-innovation by connecting rural stakeholders with global knowledge brokers - A case study from Nepal. British Food Journal 118(6), 1350-1369. DOI: 10.1108/bfj-10-2015-0398. 
[50] Halhead, V. (2006). Rural Movements in Europe: Scandinavia and the Accession States. Social Policy and Administration 40(6), 596-611. DOI: 10.1111/j.1467-9515.2006.00522.x.

[51] Hahl, T., Lintukangas, E. \& Aarrevaara, E. (2014). Sysmän taajaman muutos 1970luvulta nykypäivään. Lahti: Lahden ammattikorkeakoulun julkaisu.

[52] Hayashi, M. (2012). Japan's Fureai Kippu Time-banking in Elderly Care: Origins, Development, Challenges and Impact. International Journal of Community Currency Research 16, 30-44. DOI: 10.15133/j.ijccr.2012.003.

[53] Heikkilä, E. (2003). Differential urbanisation in Finland. Tijdschrift voor economische en sociale geografie 94(1), 49-63. DOI: 10.1111/1467-9663.00236.

[54] Heiler, F. (2008). Wie kommt das Neue ins Land? Nachhaltige Raum- und Gesellschaftsentwicklung als Gegenstand der Emergenz- und Innovationsforschung. Generierung profunder Innovation in ländlichen Kommunen [PhD Thesis] Vienna: University of Life Sciences and Natural Resource Management.

[55] Hennink, M. M. (2013). Introducing Focus Group Discussions. In Focus Group Discussions (pp. 1-34). New York, NY: Oxford University Press. DOI: 10.1093/acprof:osobl/9780199856169.003.0001.

[56] Hileman, G. (2014). From Bitcoin to the Brixton Pound: History and Prospects for Alternative Currencies (Poster Abstract). In Böhme, R., Brenner, M., Moore, T. \& Smith, M., eds., International Conference on Financial Cryptography and Data Security 2014 Lecture Notes in Computer Science, vol 8438 (pp. 163-165). Berlin: Springer. DOI: 10.1007/978-3-66244774-1_13.

[57] Hemmati, M. (2002). Multi-Stakeholder Processes for Governance and Sustainability: Beyond Deadlock and Conflict. Abingdon: Earthscan. DOI: $10.4324 / 9781849772037$.

[58] Hornborg, A. (2009). Zero-sum world challenges in conceptualizing environmental load displacement and ecologically unequal exchange in the world-system. International Journal of Comparative Sociology 50(3-4), 237-262. DOI: 10.1177/0020715209105141.

[59] Kennedy, M. (2012). Occupy money: Creating an economy where everybody wins. Gabriola Island BC: New Society Publishers.

[60] Kennedy, M., Lietaer, B. A. \& Rogers, J. (2012). People money: The promise of regional currencies. Charmouth: Triarchy Press Limited.

[61] Koenig, A. (2017). Liverpool Local Pound. In Koenig, A., ed., Cryptocoins: Investieren in digitale Währungen (pp. 122-4). München: FinanzBuch Verlag.

[62] Kotilainen, J., Eisto, I. \& Vatanen, E. (2015). Uncovering mechanisms for resilience: Strategies to counter shrinkage in a peripheral city in Finland. European Planning Studies 23(1), 53-68. DOI: 10.1080/09654313.2013.820086.

[63] Kryachkov, N. (2014). Аксиоматика политической экономии без процента. St. Petersburg: ЮПИ. DOI: 10.13140/2.1.2912.3361.

[64] Laamanen, M., Wahlen, S. \& Campana, M. (2015). Mobilising collaborative consumption lifestyles: a comparative frame analysis of time banking. International Journal of Consumer Studies 39(5), 459-467. DOI: 10.1111/ijcs.12190.

[65] Lake, O. O. (2010). Uprisings for the Earth: Reconnecting Culture with Nature. Ashland OR: White Cloud Press.

[66] Latour, B. (1996). On actor-network theory. A few clarifications plus more than a few complications. Soziale Welt 47(4), 369-381.

[67] Lee, R. (1996). Moral Money? LETS and the Social Construction of Local Economic Geographies in Southeast England. Environment and Planning A: Economy and Space 28(8), 1377-1394. DOI: 10.1068/a281377. 
[68] Lee, R., Leyshon, A., Aldridge, T., Tooke, J., Williams, C. \& Thrift, N. (2004). Making Geographies and Histories? Constructing Local Circuits of Value. Environment and Planning D: Society and Space 22(4), 595-617. DOI: 10.1068/d50j.

[69] Leydesdorff, L. (2012). The Triple Helix, Quadruple Helix, ..., and an N-Tuple of Helices: Explanatory Models for Analyzing the Knowledge-Based Economy? Journal of the Knowledge Economy 3(1), 25-35. DOI: 10.1007/s13132-011-0049-4.

[70] Libery, B. \& Kneafsey, M. (1998). Product and Place: Promoting Quality Products and Services in the Lagging Rural Regions of the European Union. European Urban and Regional Studies 5(4), 329-341. DOI: 10.1177/096977649800500404.

[71] Liebowitz, S. J. \& Margolis, S. E. (1999). Path Dependence. In Bouckaert, B. \& De Geest, G., eds., Encyclopedia of Law and Economics: The History and Methodology of Law and Economics (pp. 981-998). Northampton MA: Edward Elgar.

[72] Lietaer, B. (2001). The Future of Money. London: Random House.

[73] Lietaer, B. \& Dunne, J. (2013). Rethinking Money: How New Currencies Turn Scarcity into Prosperity. San Francisco CA: Berrett-Koehler Publishers.

[74] Ludvig, A., Weiss, G., Sarkki, S., Nijnik, M. \& Živojinović, I. (2018). Mapping European and forest related policies supporting social innovation for rural settings. Forest Policy and Economics 97, 146-152. DOI: 10.1016/j.forpol.2018.09.015.

[75] Madison, D. S. (2010). Introduction. In Madison, D. S., ed., Acts of Activism: Human Rights as Radical Performance (pp. 1-33). Cambridge: Cambridge University Press. DOI: $10.1017 / \mathrm{cbo9} 980511675973.001$.

[76] Martignoni, J. (2012). A new approach to a typology of complementary currencies. International Journal of Community Currency Research 16(A), 1-17. DOI: $10.15133 / \mathrm{j} . \mathrm{ijccr} .2012 .001$.

[77] Melo, P. \& Jorge, L. (2015). Quantitative support for UX methods identification: how can multiple criteria decision making help? Universal Access in the Information Society 14(215), 215-229. DOI: 10.1007/s10209-013-0341-0.

[78] Miller, G. \& Dingwall, R. (1997). Context and Method in Qualitative Research. London: Sage. DOI: $10.4135 / 9781849208758$.

[79] Ngugi, B., Pelowski, M. \& Ogembo, J. G. (2010). M-Pesa: A case study of the critical early adopters' role in the rapid adoption of mobile money banking in Kenya. The Electronic Journal of Information Systems in Developing Countries 43(3), 1-16. DOI: j.16814835.2010.tb00307.x.

[80] Nishibe, M. (2018). Understanding the diversity of CCs world-wide in globalization and deindustrialization as an evolutionary tree diagram. International Journal of Community Currency Research 22, 13-36. DOI: 10.15133/j.jijccr.2018.003.

[81] North, D. \& Smallbone, D. (2006). Developing entrepreneurship and enterprise in Europe's peripheral rural areas: Some issues facing policy-makers. European Planning Studies 14(1), 41-60. DOI: 10.1080/09654310500339125.

[82] North, P. (2005). Scaling alternative economic practices? Some lessons from alternative currencies. Transactions of the Institute of British Geographers 30(2), 221-233. DOI: 10.1111/j.1475-5661.2005.00162.x.

[83] Nechyba, T. J. (2016). Different Types of Tastes. Utility-Maximizing Choice: Consumers, Workers, and Savers. In Nechyba, T. J., ed., Microeconomics: An Intuitive Approach with Calculus (pp. 113-142). Boston MA: Cengage Learning.

[84] Obst, P., Zinkiewicz, L. \& Smith, S. G. (2002). Sense of community in science fiction fandom, Part 1: Understanding sense of community in an international community of interest. Journal of Community Psychology 30(1), 87-103. DOI: 10.1002/jcop.1052. 
[85] Ostrom, E. (2007). Institutional Rational Choice: An Assessment of the Institutional Analysis and Development Framework. In Sabatier, P., ed., Theories of the Policy Process (pp. 2164). Cambridge MA: Westview Press.

[86] Paterson, A. G. (2010). A Buzz between Rural Cooperation and the Online Swarm. Affinities 4(1), 83-109.

[87] Pattison, G. (2004). Planning for decline: the 'D'-village policy of County Durham, UK. Planning Perspectives 19(3), 311-332. DOI: 10.1080/02665430410001709804.

[88] Petz, M. (2017). Learning in Indigenous Mountain Forest Communities. Case studies in Northern Thailand: White Hmong (Miao), Sheleh Ladhulsi (Lahu), and Pgak'nyau (Karen) Peoples [Master Thesis]. Vienna: The University of Life Sciences and Natural Resource Management. DOI: 10.13140/RG.2.2.34209.86888.

[89] Pleschberger, W. (2003). Cities and municipalities in the Austrian political system since the 1990s. New developments between "efficiency" and "democracy". In Kersting, N. \& Vetter, A., eds., Reforming Local Government in Europe (pp. 113-135). Berlin: Springer. DOI: $10.1007 / 978-3-663-11258-7 \_6$.

[90] Ponterotto, J. G. (2006). Brief note on the origins, evolution, and meaning of the qualitative research concept thick description. The Qualitative Report 11(3), 538-549.

[91] Ram, S. \& Sheth, J. N. (1989). Consumer Resistance to Innovations: The Marketing Problem and its solutions. Journal of Consumer Marketing 6(2), 5-14. DOI: 10.1108/EUM0000000002542.

[92] Rogers, E. M. (2010). Diffusion of Innovations, $4^{\text {th }}$ ed. New York NY: Simon and Schuster.

[93] Roots, L. \& Dumbrava, C. (2016). E-Citizenship Opportunities in the Changing Technological Environment. In Kerikmäe, T. \& Rull, A. eds., The Future of Law and eTechnologies (pp. 4556). Cham: Springer International Publishing. DOI: 10.1007/978-3-319-26896-5_3.

[94] Sachy, M. (2017). Money for the Common Wealth of the Multitude: Toward a User-Managed Currency and Payment System Design [PhD Thesis]. The University of Leicester.

[95] Sampson, K. A. \& Goodrich, C. G. (2009). Making Place: Identity Construction and Community Formation through "Sense of Place" in Westland, New Zealand. Society and Natural Resources 22, 901-915. DOI: 10.1080/08941920802178172.

[96] Samuelson, P. A. (1997). Exchange, Division of Labor, and Money. In Samuelson, P. A., ed., Economics: The Original 1948 edition (pp. 51-59). New York, NY: McGraw-Hill Education.

[97] Schneider, W. E. (1994). The Reengineering Alternative: A plan for making your current culture work. New York NY: McGraw Hill.

[98] Schultz, D. E., Tannenbaum, S. I. \& Lauterborn, R. F. (1993). A History of Integrated Marketing Communications: Why Is It Important Now? In Schultz, D. E., Tannenbaum, S. I. \& Lauterborn, R. F., eds., The new marketing paradigm: Integrated marketing communications (pp. 1-14). Chicago: NTC Business Books.

[99] Seaton, A. V. (1999). Book towns as tourism developments in peripheral areas. International Journal of Tourism Research 1(5), 389-399. DOI: 10.1002/(sici)15221970(199909/10)1:5<389::aid-jtr204>3.0.co;2-0.

[100] Skeldon, R. (1997). Rural-to-urban migration and its implications for poverty alleviation. Asia-Pacific Population Journal 12(1), 3-16. DOI: 10.18356/cd2c964e-en.

[101] Stingl, Al. (2015). The Rural Imaginary: Integrated Interdisciplinarity in the Study of the Political Bioeconomy. In Bakker JI, ed., The Methodology of Political Economy: Studying the Global Rural-Urban Matrix (pp. 167-190). London: Lexington Books.

[102] Taylor, S., Bogdan, R. \& DeVault, M. (2016). Introduction to Qualitative Research Methods: A Guidebook and Resource $4^{\text {th }}$ ed. Hoboken, NJ: John Wiley \& Sons. Inc. 
[103] Valek, L. \& Bures, V. (2019). Time Bank as a Complementary Economic System: Emerging Research and Opportunities. Hershey PA: IGI Global.

[104] van Meeteren, M. \& Poorthuis, A. (2018). Christaller and "big data": recalibrating central place theory via the geoweb. Urban Geography 39(1), 122-148. DOI: 10.1080/02723638.2017.1298017.

[105] Varoufakis, Y. (2016). And the Weak Suffer What They Must? Europe, Austerity and the Threat to Global Stability. London: Random House.

[106] Vauramo, T. E., Rante, S., Taegen, J. \& Verma, I. (2018). Sote-palvelut muuttuvat uudistuksesta huolimatta. Aalto university.

[107] Walsh, A. (2009). Quick response codes and libraries. Library Hi Tech News 26(5/6), 7-9. DOI: $10.1108 / 07419050910985255$.

[108] Weber, M. (1978). The City (Non-Legitimate Domination), translation of German published 1922. In Roth, G. \& Wittich, C. eds., Economy and Society: An Outline of Interpretive Sociology (pp. 1212-1372). Berkeley CA: University of California Press.

[109] Wolman, D. (2013). The End of Money: Counterfeiters, Preachers, Techies, Dreamers and the Coming Cashless Society. Philidelphia PA: Da Capo Press.

[110] Zenker, S. \& Braun, E. (2010). The place brand centre - A conceptual approach for the brand management of places. In Beckmann S., Ringberg, C. \& Ritter, T., eds., $39^{\text {th }}$ European Marketing Academy Conference (pp. 1-8). Copenhagen: Denmark Copenhagen Business School.

Other sources

[111] Arvotakomo (2019). Valuecraft > About. Available from: https://valuecraft.coop/about/.

[112] European Union, (2004). Annex I list referred to in article III-226 of the constitution i.e. The Treaty on the Functioning of the European Union here defining Agricultural products. Official Journal of the European Union.

[113] K-rhymä (2017). Näin otat K- Plussan mobiilikortin käyttöön. Available from: https://www.youtube.com/watch?time_continue=35\&v=EgVUmSXQiZg.

[114] Kesko (2016). K-Plussa in English. Available from: https://www.plussa.com/K-Plussa-inEnglish/.

[115] Kesko (2019). K-Plussa-mobiilikortti. Available from: https://www.plussa.com/Mobiilikortti/.

[116] Kintetsu Group (2018). KIPSトップページ >「近鉄ハルカスコイン」社会実験概要 > 詳 細 >よくあるご質問. (Translates as: KIPS top page > Outline of "Kintetsu Harukas coin" social experiment $>$ Details $>$ FAQ). Available from: https://www.kintetsu.co.jp/group/Kips/harukas-coin/faq.html.

[117] Lahti Region Ltd. (2017). Webpage image with text. Available from: https://visitlahti.fi/en.

[118] Levy, H. What's New in Gartner's Hype Cycle for Emerging Technologies (2015). (Stamford CT: Gartner, Inc.). Available from: http://www.gartner.com/smarterwithgartner/whats-new-ingartners-hype-cycle-for-emerging-technologies-2015/. Archived at http://www.webcitation.org/6fxKihDcX.

[119] Maa- ja metsätalousministeriö (2013). Local food - but of course!: Government Programme on Local Food and development objectives for the local food sector to 2020. Helsinki: Ministry of Agriculture and Forestry.

[120] Manelius, T. Legislation on regional development. (Helsinki: Työ- ja elinkeinoministeriö / Ministry of Economic Affairs and Employment of Finland). Available from: https://tem.fi/en/legislation-on-regional-development. 
[121] David McCarthy, D. and Reidelbach, M., (2016). Keep it Local! Grassroots Economic Organizing (GEO). Available from: http://www.geo.coop/story/keep-it-local.

[122] MMM (1964). Mitä Missä Milloin 1964: Kansalaisen Vuosikirja. Helsinki: Otava Oy.

[123] MLIT (2017). Country Report: Finland. Tokyo: National Spatial Planning and Regional policy Bureau, Japanese Ministry of Land, Infrastructure, Transport and Tourism.

[124] OSF (2018). Sysmä Preliminary population by Area, Month and Sex. ISSN=1797-5395. Official Statistics of Finland interface service (Helsinki: Statistics Finland). Available from: http://www.stat.fi/til/vaerak/2018/vaerak_2018_2019-03-29_tie_001_en.html.

[125] OSF (2019). Dwellings and housing conditions. ISSN=1798-6761. Official Statistics of Finland interface service (Helsinki: Statistics Finland). Available from: http://www.stat.fi/til/asas/index_en.html.

[126] PHL (2017). Maakuntahallitus minutes 14.08.2017, 107 Alueelliset innovaatiot ja kokeilut rahoituksen myöntäminen hankkeelle Sysmän kuponkieuro ja pienyrittäjien verkosto (Lahti: Päijät-Hämeen liitto). 14.08.2017. Available from: http://dynasty.phame.emedia.fi/kokous/2017162-11.HTM.

[127] PHL (2019). Kuponkieuro ja Pienyritysten Verkosto Loppuraportti. No author given, but most probably Nieminen, J. (Project Manager in Sysmä) as he is listed in the word document metadata as the author. (Lahti: Päijät-Hämeen liitto).

[128] Saarinen, U-M. (2011). Suomessa väki keskittyy taajamiin. (Helsinki: Statistics Finland). Available from: http://www.stat.fi/tup/vl2010/art_2011-12-16_001.html.

[129] Simola, M. (2017). LIITE 1: HANKESUUNNITELMA: hankkeen tavoitteet, konkreettiset toimenpiteet ja Vaikutukset: Sysmän kuponkieuro ja pienyrittäjien verkosto, Ketterät kokeiluhankkeet. Available from:

https://www.sysma.fi/library/files/5a33b7f1c910586ff1000f25/HANKESUUNNITELMA_AIK O_Sysm_n_kuponkieuro_ja_pienyritt_jien_verkosto.pdf.

[130] S Group (2019). S Group's Annual and Responsibility Report 2018. (Helsinki: S Group). Available from: https://www.s-kanava.fi/web/s-ryhma/en/vuosikatsaus/etusivu.

[131] SF (2019). 185 - Media equipment use, those aged 10 or over (2002 / 2017) \%. Statistics Finland's PxWeb databases (Helsinki: Statistics Finland). Available from: http://pxnet2.stat.fi/PXWeb/pxweb/en/StatFin/StatFin_eli_vpa_Tieto_ja_viestintatekniik ka/statfin_vpa_pxt_185.px/.

[132] Spotless (2017). Spotless service design agency. When and How to Use Ethnographic Research. San Francisco: Medium. Available from: https://medium.com/@spotint/whenand-how-to-use-ethnographic-research-b57905a3b290.

[133] Talasterä, J. and Sources YLE. (2017). Southern Finland micro-municipality to trial independent currency in 2018. YLE Uutiset. Helsinki: YLE.

[134] The Lewes Pound, The Lewes Pound. Lewes: The Lewes Pound. Available from: https://www.thelewespound.org.

[135] Triple Helix Research Group, The Triple Helix concept. Stanford CA: Stanford University. Available from: http://triplehelix.stanford.edu/3helix_concept.

[136] Tuomikoski, M. (2018). Pikkukunnalta rohkea päänavaus: Sysmä ottaa käyttöön kaikille suomalaisille avoimen e-kuntalaisuuden. YLE Uutiset. Helsinki: YLE. Available from https://yle.fi/uutiset/3-10396372.

[137] Vanhanen, J. (2015). A film called Aikamatka Sysmän Historiaan (Translation: Timetravel into Sysmän History) Finland.

[138] Waldviertler - Verein für regionales Wirtschaften (2016). 2. Sondernewsletter. Heidenreichstein: Waldviertler - Verein für regionales Wirtschaften. Available from: http://www.waldviertler-regional.at/downloads/SONDERNEWSLETTER.pdf. 